\title{
Hubungan antara jenis asupan karbohidrat dan lemak dengan kadar small dense low density lipoprotein pada pasien penyakit jantung koroner
}

\author{
Sefri Noventi Sofia ${ }^{1 *}$, Sugiri ${ }^{1}$, Sulistiyati Bayu Utami ${ }^{1}$, M. Arif Nugroho ${ }^{1}$, Etisa Adi Murbawani²
}

\begin{abstract}
Background: small dense Low Density Lipoprotein (sdLDL) was the most atherogenic lipoprotein. Its influenced by internal and external factors including food consumption. Indonesian people mostly take a diet of high carbohydrate (CH) and fried food that believed to correlate with higher sdLDL level and predisposed to Coronary Heart Disease (CHD). There were 2 types of $\mathrm{CH}$ based on the processing ways, refined and non-refined $\mathrm{CH}$.

Objectives: The study's purpose was to prove the correlation between different types of $\mathrm{CH}$ and fat intake with the sdlDL level in CHD patients.

Methods: cross sectional in CHD patients hospitalized at Dr Kariadi hospital. The sdLDL and others lipid profile examined. The type and amount of $\mathrm{CH}$ and fat intakes per-day were collect from an interview using semi-quantitative food frequency questionnaire (SQFFQ) and food models. Pearson and Spearman test used for bivariate analysis. Confounding factors age, gender, physical activity, diabetes mellitus and smoking were analyzed. Variables with $p<0,25$ was included in multivariate analysis using linear regression test.

Results: There were 30 samples with CHD came with acute coronary syndrome (ACS). Mean of total CH intake per day was 267.75 gram. Mean of percentage of CH from total calories per day was 55.93\%. This number was higher than advised which is 30-130 gram or <45\% of total calorie per day. Mean of refined and non-refined CH intake was 161.80 and $57.81 \mathrm{gr} / \mathrm{day}$. The total CH mostly from refined $\mathrm{CH}(76 \%)$ rather than non-refined. Mean of fat intake was $68 \mathrm{gr} /$ day $(32.76 \%$ of total energy per day), and the mean of sdLDL level was $26,54 \mathrm{mg} / \mathrm{dl}$. Correlation between refined $\mathrm{CH}$ vs non-refined $\mathrm{CH}$ with the sdLDL levels $(r=0.328 ; p=0.077$ vs $r=-0.184 ; p=0.331)$. Correlation between fat intake and sdLDL levels $(r=0.44 ; p=0.15)$. Multivariate analysis was analyzing refined $\mathrm{CH}$ fat intake and age with sdLDL level $(r=0,28 ; p=0,13 \mathrm{vs} r=0.45 ; p=0.01 \mathrm{vs} r=-$ $0.15 ; p=0.44)$. There is significant correlation between fat intake and sdLDL levels with $r=0.45$

Conclusion: There was a significant correlation between fat intake and sdLDL levels in CHD patients. There is no significant correlation between refined and non-refined carbohydrates with sdLDL levels in CHD patients.
\end{abstract}

Key words: refined carbohydrate, fat intake, sdLDL, coronary heart disease

\section{ABSTRAK}

Latar belakang: small dense Low Density Lipoprotein (sdLDL) merupakan lipoprotein yang paling aterogenik. Kadar sdLDL dipengaruhi oleh faktor internal dan faktor eksternal (asupan makanan). Pola makan di Indonesia yang tinggi karbohidrat (KH) dan makanan yang digoreng diduga berperan meningkatkan kadar sdLDL yang merupakan faktor risiko Penyakit Jantung Koroner (PJK). Terdapat 2 jenis besar KH berdasarkan pengolahannya, yaitu refined dan non-refined.

Tujuan: Penelitian ini bertujuan untuk membuktikan hubungan antara beberapa jenis asupan karbohidrat dan lemak dengan kadar sdLDL pada pasien PJK.

Metode: studi belah lintang dengan sampel pasien PJK yang dirawat di RS Dr Kariadi. Kadar sdLDL dan profil lipid diukur dari pengambilan darah vena. Asupan karbohidrat beserta jenis karbohidrat dan lemak per-hari diambil dari semiquantitative food frequency questionnaire (SQFFQ) dengan food model. Karbohidrat dikelompokkan menjadi refined dan nonrefined. Variabel perancu usia, jenis kelamin, aktifitas fisik, diabetes mellitus dan merokok. Uji analisis bivariat dilakukan dengan uji pearson dan spearman, uji multivariat dilakukan pada variabel perancu dengan $p<0,25$ dengan uji regresi linear.

Hasil: Didapatkan 30 sampel penelitian dengan PJK dengan sindroma koroner akut (SKA). Rerata asupan karbohidrat total pasien PJK per hari adalah 267,75 gram, dengan rerata persentase karbohidrat dibanding total kalori adalah 55,93\%. Angka ini lebih tinggi dari jumlah asupan karbohidrat total yang dianjurkan yaitu 30-130 gram atau <45\% dari total kalori per hari. Rerata asupan karbohidrat refined dan karbohidrat non-refined adalah 161,80 dan 57,81 gr/hari. Jenis asupan karbohidrat sebagian besar (76\%) berasal dari KH refined. Rerata asupan lemak pasien PJK adalah 68 gr/hari (32,76\% dari total energi per hari), dengan rerata kadar sdLDL 26,54 mg/dl. Uji korelasi antara $K H$ refined vs $K H$ non-refined dengan $s d L D L$ $(r=0,328 ; p=0,077$ vs $r=-0,184 ; p=0,331)$, dan korelasi lemak dengan kadar sdLDL $(r=0,44 ; p=0,015)$. Analisis multivariat asupan karbohidrat refined, asupan lemak dan usia terhadap sdLDL ( $r=0,28 ; p=0,13$ vs $r=0,45 ; p=0,01$ vs $r=-0,15 ; p=0,44)$. Terdapat hubungan signifikan antara asupan lemak dengan kadar sdLDL dengan $r=0,45$.

Simpulan: Terdapat hubungan yang signifikan antara asupan lemak dan kadar sdLDL pada pasien PJK. Tidak terdapat hubungan yang signifikan antara asupan karbohidrat refined dan non-refined dengan kadar sdLDL pasien PJK.

Kata kunci: karbohidrat refined, asupan lemak, sdLDL, penyakit jantung coroner

Penelitian ini pernah dipresentasikan di pertemuan ilmiah $1^{\text {st }}$ International Conference on Preventive Medicine (ICPM) 2018, 2-3 Mei 2018 di Malang

${ }^{1}$ Departemen Kardiologi dan Kedokteran Vaskular, Fakultas Kedokteran, Universitas Diponegoro. J1. Dr. Sutomo No 16, Semarang, Jawa Tengah. 50231.

${ }^{2}$ Departemen Ilmu Gizi, Fakultas Kedokteran, Universitas Diponegoro. Jl. Prof. Sudarto SH, Tembalang, Semarang, Jawa Tengah 50275.

*Korespondensi: E-mail: sefrinov@gmail.com. Telp/HP: 081325338889

Copyright $\odot$ 2018; Jurnal Gizi Indonesia (The Indonesian Journal of Nutrition), 7 (1), 2018

e-ISSN : 2338-3119, p-ISSN: 1858-4942 


\section{PENDAHULUAN}

Hingga saat ini Penyakit Jantung Koroner (PJK) masih merupakan penyebab kematian tertinggi di dunia, termasuk di Indonesia, dimana data Departemen Kesehatan Tahun 2013, prevalensi PJK di Indonesia didapatkan $1,5 \%$ dan cenderung meningkat. ${ }^{1}$ Meskipun menjadi pembunuh utama, tetapi masih belum banyak orang yang mengetahui tentang PJK dan faktor risikonya. PJK merupakan manifestasi dari aterosklerosis. Menurut data WHO tahun 2008, kurang lebih sepertiga dari kejadian PJK disebabkan oleh dislipidemia. Dislipidemia adalah gangguan metabolisme lipid yang ditandai dengan kadar kolesterol dan atau trigliserida (TG) yang diangkut oleh lipoprotein kilomikron, very low density lipoprotein (VLDL), intermediate density lipoprotein (IDL), low density lipoprotein (LDL), dan high density lipoprotein (HDL) yang tidak normal. Di Indonesia prevalensi dislipidemia pada dewasa kurang lebih 30-40\%. ${ }^{2}$

Guidelines American College of Cardiology (ACC)/ American Heart Asociation (AHA) terbaru 2013 tidak merekomendasikan kadar LDL kolesterol sebagai target terapi. Sampai saat ini belum ada penelitian dengan statin yang memberikan manfaat yang didasarkan pada kadar LDL kolesterol basal atau kadar target LDL kolesterol. Penurunan kadar LDL kolesterol yang signifikan hanya berkaitan dengan penurunan 30-37\% dari kejadian PJK pada populasi, sedangkan sisanya tetap mengalami progresifitas. ${ }^{3,4} \mathrm{Hal}$ ini mungkin disebabkan pada LDL kolesterol dengan kadar yang normal bisa mengandung small dense low density lipoprotein (sdLDL) dengan kadar yang tinggi yang bersifat lebih aterogenik yang dapat meningkatkan risiko $\mathrm{PJK} .^{5}$

Kadar lipid darah, termasuk sdLDL, pada dasarnya dipengaruhi oleh 2 faktor: faktor risiko internal dan eksternal. Salah satu faktor risiko eksternal yang memegang peranan penting yaitu asupan makanan dan minuman. Hubungan antara karbohidrat dan lemak dengan sdLDL diduga berhungan dengan peningkatan kadar trigliserida. Kondisi kaya trigliserida ini akan mengubah komposisi inti dari lipoprotein menjadi inti dengan rasio antara kolesterol banding trigliserida yang lebih kecil sehingga lipoprotein menjadi lebih kecil dan padat yang memiliki sifat aterogenik yang lebih kuat. ${ }^{6}$ Sifat ini yang didapatkan pada sdLDL. Masukan energi yang berlebihan yang berasal dari karbohidrat dan lipid dapat meningkatkan kadar trigliserida dan kolesterol dalam darah. ${ }^{7}$ Di Indonesia sendiri dari hasil analisis Survei Konsumsi Makanan Individu (SKMI) 2014 menunjukkan bahwa mayoritas penduduknya mengkonsumsi karbohidrat yang cukup banyak yaitu $60-70 \%$ dari total kalori (97,7\% dari beras) dan banyak makanan yang digoreng. ${ }^{8}$ Komposisi ini lebih tinggi dari yang dianjurkan untuk pencegahan PJK yaitu karbohidrat $<45 \%$ dari total kalori per hari. Karbohidrat berdasarkan pengolahannya dibedakan menjadi karbohidrat refined yaitu yang telah mengalami pengolahan dan karbohidrat non-refined yang tidak mengalami banyak proses pengolahan. Beberapa penelitian sebelumnya mencoba melihat hubungan antara asupan makanan karbohidrat, lemak terhadap kadar profil lipid konvensional seperti trigliseride, LDL cholesterol, HDL cholesterol. Belum ada yang melakukan penelitian hubungan antara beberapa jenis asupan karbohidrat dan lemak dengan kadar sdLDL pada pasien PJK di Indonesia. Penelitian ini ingin melihat bagaimana pola makanan pasien PJK dan melihat hubungan antara asupan karbohidrat refined, karbohidrat non-refined dan lemak dengan kadar sdLDL pada pasien dengan penyakit jantung koroner.

\section{BAHAN DAN METODE}

Penelitian ini merupakan penelitian analitik observasional dengan rancangan cross sectional. Penelitian telah mendapat ijin dari Komisi Etik Penelitian Kesehatan (KEPK) Fakultas Kedokteran Universitas Diponegoro dan RSUP Dr Kariadi Semarang Nomor 300/EC/FK-RSDK/V/2017. Sampel penelitian adalah 30 pasien PJK yang dirawat di RS Dr Kariadi Semarang periode Juni hingga November 2017 yang datang ke RS Dr Kariadi dengan Sindroma Koroner Akut (SKA) berusia kurang 30-70 tahun. Pasien dengan sirosis hepatis, penyakit tiroid, obesitas, gangguan fungsi ginjal berat, gangguan daya ingat, dan yang telah mengkonsumsi obat lipid modulator, kortikosteroid dan kontrasepsi dieksklusi dari penelitian. Pasien yang datang ke RS Dr Kariadi dengan ACS yang memenuhi kriteria inklusi dan tidak memiliki kriteria eksklusi dan setuju menandatangani informed consent akan segera dilakukan pengambilan darah vena. Darah akan disentrifugasi dan disimpan pada suhu $20{ }^{\circ} \mathrm{C}$ hingga kemudian digunakan. Kadar sdLDL diperiksa secara direk dari darah vena (satuan $\mathrm{mg} / \mathrm{dl}$ ) dengan metode ELISA melalui laboratorium Prodia Semarang. Selanjutnya dilakukan wawancara oleh ahli giz dengan menggunakan Semiquantitative Food Frequency Questionnaire (SQ FFQ) yang telah tervalidasi dan food models dengan satuan gram per hari (gr/hr) untuk mengetahui asupan karbohidrat refined, karbohidrat non-refined dan lemak. Jenis karbohidrat refined dan non-refined dibedakan berdasarkan cara pengolahannya (tercatat dalam SQ FFQ) yaitu karbohidrat refined adalah karbohidrat yang halus dan sudah mengalami proses pengolahan seperti: roti, mie, nasi putih, pasta, ketan, gula, sirup, es krim. Karbohidrat non-refined adalah karbohidrat kompleks yang alami dan tidak/sedikit mengalami proses pengolahan, seperti: sayur, buah, kentang, beras yang masih ada kulit arinya. Hubungan antara karbohidrat 

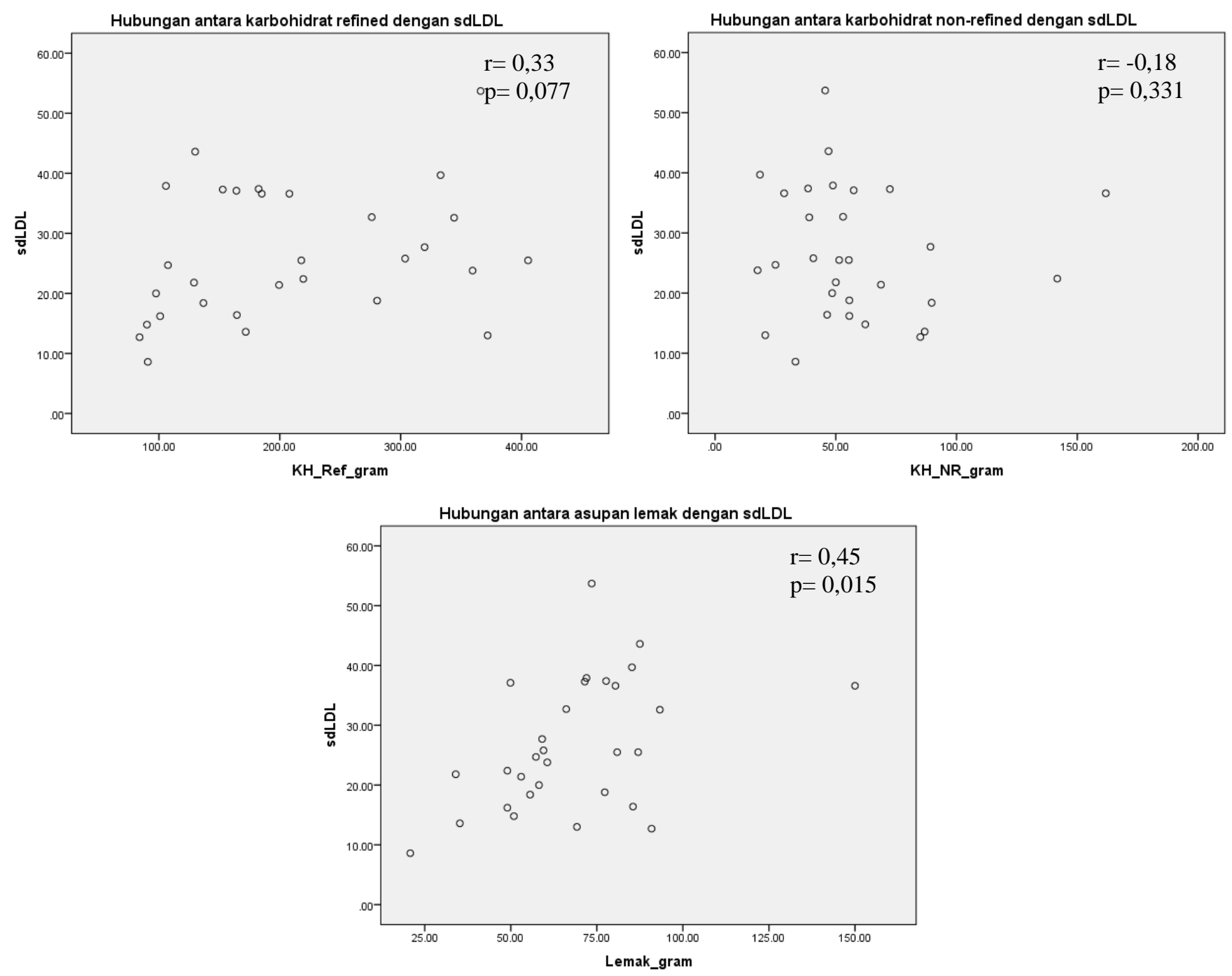

Gambar 1. Hubungan antara Asupan Karbohidrat dan Asupan Lemak dengan Kadar sdLDL

Tabel 3. Analisis Variabel Perancu dengan sdLDL

\begin{tabular}{lc}
\hline \multicolumn{1}{c}{ Variabel } & $\boldsymbol{p}$ \\
\hline Usia & $0,246^{*}$ \\
Diabetes melitus & $0,679^{\#}$ \\
Aktifitas fisik & $0,365^{\#}$ \\
Jenis kelamin & $0,886^{\#}$ \\
Merokok & $0,622^{\#}$ \\
\hline pearson test $;{ }^{*}$-test &
\end{tabular}

Tabel 4. Analisis Multivariat

\begin{tabular}{lcc}
\hline \multicolumn{1}{c}{ Variabel } & r & $\boldsymbol{p}$ \\
\hline Asupan karbohidrat refined & 0,28 & 0,13 \\
Asupan lemak & 0,45 & 0,01 \\
Usia & $-0,15$ & 0,44 \\
\hline
\end{tabular}

\section{PEMBAHASAN}

Mayoritas subset SKA pada sampel pasien ini adalah STEMI. Studi registri dari McManus yang menganalisis pasien yang dirawat dengan SKA menunjukkan adanya kecenderungan penurunan prevalensi STEMI, dan sebaliknya terjadi kecenderungan peningkatan prevalensi NSTEMI. Penurunan prevalensi STEMI ini diduga berkaitan dengan perbaikan upaya pencegahan, dan penatalaksanaan komorbid yang lebih baik di klinik layanan primer. ${ }^{9}$ Pada sampel penelitian ini prevalensi STEMI masih tinggi dimungkinkan karena kurangnya pengetahuan masyarakat tentang PJK, faktor-faktor risiko PJK dan penatalaksanaan faktor risiko PJK.

Rerata usia pada sampel penelitian ini adalah 55 tahun, 13,3\% sampel mengalami kejadian SKA pada usia dibawah 40 tahun. Rerata usia ini lebih muda dibanding rerata pasien SKA pada populasi di Eropa dan Amerika yaitu 67-73 tahun. ${ }^{9}$ Hal ini mungkin dikarenakan perbedaan pola hidup dan masih kurangnya pengetahuan tentang faktor-faktor risiko PJK dan upaya pencegahannya. Perbedaan pola hidup seperti pola makanan, merokok dan kurangnya aktifitas fisik juga berpengaruh untuk terjadinya SKA di usia yang lebih muda. Di Indonesia yang merupakan salah satu produsen rokok terbesar di dunia, memiliki prevalensi perokok yang tinggi, dibuktikan dengan prevalensi perokok pada sampel penelitian ini adalah $77,3 \%$ pria. 
Perbedaan pola makanan juga berpengaruh pada tingginya prevalensi SKA pada usia muda. Pola makanan seperti gorengan, santan, dan makanan karbohidrat high-refined seperti tepung, nasi dan gula meningkatkan risiko PJK.

Di negara berkembang, kurang lebih $80 \%$ produksi energi berasal dari karbohidrat, sedangkan pada negara maju lebih rendah yakni $50 \%$ energi yang berasal dari karbohidrat. ${ }^{10}$ Data dari SKMI menunjukkan rerata asupan karbohidrat di Indonesia adalah $60-70 \%$ dari total kalori. ${ }^{8}$ Rerata asupan karbohidrat total pada sampel penelitian ini adalah 55.93\% dari total kalori. Angka ini lebih rendah dari data SKMI dimungkinkan karena rerata sampel penelitian ini tinggal didaerah perkotaan yang cukup maju dengan ketersediaan lemak dan protein yang cukup baik, akan tetapi angka ini lebih tinggi bila dibandingkan dengan komposisi yang dianjurkan untuk gizi seimbang dan pencegahan PJK yaitu $<45 \%$ dari total kalori per hari.

Proporsi diet yang dianjurkan untuk pencegahan penyakit jantung adalah rendah karbohidrat, yaitu 30130 gram per hari atau $<45 \%$ dari total kalori per hari. ${ }^{11}$ Pada sampel penelitian ini, dari hasil anamnesis asupan makanan perhari didapatkan semua pasien (100\%) mengkonsumsi total karbohidrat $>130$ gram perhari, dan 25 pasien $(83.33 \%)$ mengkonsumsi karbohidrat total $>45 \%$ dari total kalori per hari. Bila dibagi dari proses pengolahannya, tampak dari Tabel 1 bahwa sebagian besar sampel penelitian ini mengkonsumsi asupan karbohidratnya dari karbohidrat refined dibanding karbohidrat non-refined. Dari data wawancara SQ FFQ hanya 1 sampel penelitian yang mengkonsumsi proporsi karbohidrat non-refined sama banyaknya dengan karbohidrat refined.

Selama berpuluh tahun karbohidrat dikenal sebagai pilar diet yang sehat. Studi dari British Medical Research Counsil yang mengganti diet mengurangi lemak dan menggantinya dengan karbohidrat tidak menunjukkan perbedaan yang bermakna terhadap keluaran penyakit kardiovaskular. ${ }^{12}$ Beberapa penelitian berikutnya menunjukkan tipe dan kualitas karbohidrat lebih berperan pada sistem kardiometabolik. $^{13}$ Karbohidrat tipe refined adalah karbohidrat yang telah mengalami pengolahan sehingga telah mengalami perubahan struktur dan kandungan mikronutrien dan pengurangan kandungan serat, beberapa juga ditambahkan gula atau garam dalam pengolahannya. Karbohidrat refined dikatakan memiliki molekul yang lebih kecil sehingga lebih cepat mengalami proses absorbsi di usus, lebih cepat dimetabolisme oleh enzimenzim digestif, dan lebih mudah terjadi lonjakan kadar glukosa dalam plasma. ${ }^{14}$

Beberapa studi telah menganalisis hubungan antara jenis karbohidrat ini dengan kadar trigliserid yang diduga menjadi menjadi perantara dalam hubungan karbohidrat dengan sdLDL. Pada subanalisis penelitian ini didapatkan hasil asupan karbohidrat refined berhubungan positif lemah yang secara statistik tidak signifikan dengan kadar trigliserid, hubungan ini tampaknya lebih kuat dibanding hubungan antara karbohidrat dengan kadar cholesterol total, LDL dan HDL yang didapatkan kekuatan hubungan sangat lemah. Di sisi lain, karbohidrat non-refined berhubungan negatif yang sangat lemah dan tidak signifikan dengan semua profil lipid yaitu trigliserid, cholesterol total, LDL dan HDL. Hal ini mendukung teori bahwa karbohidrat non-refined yang tidak diolah bersifat protektif terhadap kejadian PJK dimana nonrefined karbohidrat yang tidak atau sedikit diolah masih mengandung banyak serat dan kadar glikemik indek yang rendah sehingga tidak meningkatkan trigliserid dan kolesterol secara signifikan.

Hasil penelitian ini hampir serupa dengan temuan Sugiri yang mendapat hubungan positif yang signifikan dengan kadar trigliserid. Kemungkinan yang bisa menjelaskan perbedaan signifikansi ini adalah perbedaan usia sampel penelitian, dimana karakteristik sampel penelitian Sugiri hanya meneliti pada pasien PJK usia muda yaitu kurang dari 50 tahun. ${ }^{15}$ Pada penelitian ini tidak dikhususkan pada pasien PJK muda, dengan rentang usia sampel penelitian 32-69 tahun dengan median usia 59 tahun. Pada usia yang lebih tua kemungkinan faktor yang mempengaruhi kadar sdLDL lebih didominasi faktor internal dibandingkan faktor eksternal seperti asupan makanan. Selain perbedaan usia, subset klinis sampel penelitian ini juga berbeda dengan penelitian Sugiri dan penelitian lainnya yaitu pada pasien PJK yang stabil, sedangkan pada penelitian ini meneliti pada sampel pasien PJK yang tidak stabil atau dengan klinis SKA. Karakteristik profil lipid pasien PJK dalam kondisi SKA mungkin berbeda dengan pasien PJK saat kondisi stabil. Pemberian terapi statin yang merupakan terapi standar pasien SKA mungkin juga mempengaruhi hasil penelitian ini, meskipun mungkin sangat kecil karena pemberian statin pada sampel penelitian ini hanya diberikan kurang dari 24 jam dari pengambilan sampel darah sdLDL dan profil lipid.

Beberapa penelitian lain menunjukkan hubungan antara asupan karbohidrat dengan kadar trigliserid, cholesterol total, LDL, dan HDL yang berbeda-beda. Dietary Intervention Randomized Controlled Trial (DIRECT) meneliti populasi obesitas yang diberikan diet rendah karbohidrat menunjukkan penurunan kadar trigliserid dan peningkatan kadar HDL, kadar LDL tidak berubah. ${ }^{11}$ Studi lain menunjukkan bahwa mengganti diet $1 \%$ lemak tersaturasi dengan $1 \%$ karbohidrat dikatakan akan meningkat kadar trigliserid $1 \mathrm{mg} / \mathrm{dl} .{ }^{12}$ Hal ini serupa juga ditemukan oleh EJ Parks, et al, dimana didapatkan asupan karbohidrat yang tinggi menyebabkan peningkatan trigliserida. ${ }^{16} \mathrm{Di}$ sisi lain, 
Karakas S Kasim, et al, meneliti pada 14 orang wanita sehat postmenopausal dan mendapatkan peningkatan asupan makanan menyebabkan peningkatan kadar trigliserida, tetapi tidak didapatkan dari hubungan antara asupan karbohidrat dengan kadar kolesterol, HDL dan LDL. ${ }^{17}$ Yang perlu juga menjadi dipertimbangkan adalah meskipun dalam temuan didapatkan hubungan yang secara statistik tidak bermakna, namun kemungkinan hubungan ini secara klinis tidak dapat diabaikan.

Dari hasil analisis multivariat tampak bahwa asupan lemak memiliki hubungan dengan kekuatan sedang yang signifikan dengan kadar sdLDL, sedangkan variabel usia tidak berhubungan secara signifikan dengan kadar sdLDL. Hal ini mendukung penelitian-penelitian sebelumnya yang lebih konsisten menunjukkan hubungan positif diantara asupan lemak dan sdLDL. Lipid merupakan salah satu komponen pembentuk lipoprotein termasuk sdLDL. Rerata asupan lemak pada sampel penelitian ini adalah 33\% dari total kalori per hari, angka ini lebih tinggi dari diet asupan lemak yang direkomendasikan pada pasien PJK yaitu $<30 \%$ dari total kalori. ${ }^{11}$

\section{SIMPULAN}

Terdapat hubungan yang signifikan antara asupan lemak dengan kadar sdLDL pada pasien PJK. Tidak terdapat hubungan yang signifikan antara asupan karbohidrat refined dan karbohidrat non-refined dengan kadar sdLDL pasien PJK. Saran dilakukan penelitian intervensi eksperimental untuk melihat hubungan antara berbagai jenis asupan karbohidrat dan lemak dengan kadar sdLDL dan kadar lipid konvensional lain dengan besar sampel yang lebih besar.

\section{DAFTAR PUSTAKA}

1. Supriyantoro, Primadi O, Vensya S, Budijanto D, Hardhana B, F S, dkk. Profil kesehatan indonesia tahun 2013. Jakarta: Kementrian Kesehatan RI; 2014

2. Global health observatory map gallery. 2011

3. Sharma SB, Garg S. Small dense ldl: Risk factor for coronary artery disease (cad) and its therapeutic modulation. Indian $\mathrm{J}$ Biochem Biophys. 2012;49:77-85

4. Stone NJ, Robinson J, Lichtenstein AH, Merz CN, Blum CB, Eckel RH, et al. Acc/aha guideline on the treatment of blood cholesterol to reduce atherosclerotic cardiovascular risk in adults: A report of the american college of cardiology/american heart association task force on practice guidelines. Circulation. 2013;129:S1-45

5. Lamarche B, Tchernof A, Moorjani S, Cantin B, Dagenais GR, Lupien PJ, et al. Small, dense low- density lipoprotein particles as a predictor of the risk of ischemic heart disease in men. Prospective results from the que bec cardiovascular study. Circulation. 1997;95:69-75

6. Yazdandoust S, Parizadeh SM, Moohebati M, Yaghmaei P, Rahsepar AA, Tavallaie S, et al. Serum small dense low-density lipoprotein concentrations are elevated in patients with significant coronary artery stenosis and are related to features of the metabolic syndrome. Lipids. 2012;47:963-972

7. Yulissa F. Pengaruh pemberian daging buah durian (Durio zibethinus L.) terhadap kadar profil lipid darah sukarelawan sehat [skripsi]. Medan (Indonesia): Universitas Sumatra Utara; 2013: 8-20

8. Kementrian Kesehatan Republik Indonesia. Studi diet total : potret pola makan penduduk indonesia saat ini [internet]. 2015 [cited 2016 Jan 3]. Available from: www.depkes.go.id

9. McManus DD, Gore J, Goldberg RJ. Recent trends in the incidence, treatment, and outcomes of patients with ST and Non-ST segment acute myocardial infarction. Am J Med. 2011 Jan; 124(1): 40-7

10. Almatsier S. Prinsip dasar ilmu gizi.Jakarta: PT. Gramedia Pustaka Utama;2001:28-47

11. Adar SE, Sinai T, Yosefy C, Henkin Y. Nutritional recommendationsfor cardiovascular disease prevention. Nutrients. 2013; 5:3646-83

12. Sacks FM, Lichtenstein AH, WU JHY, Appel LJ, Creager MA, Etherton PM, et al. Dietary fats and cardiovascular disease: a presidential advisory from the american heart association. Circulation. 2017; 135:00

13. Mozzafarian D. Dietary and policy priorities for cardiovascular disease, diabetes, and obesity: a comprehensive review. Circulation. 2016; 133: 187-225

14. Hu FB. Are refined carbohydrates worse than saturated fat?. Am J Clin Nutr. 2010; 91: 1541-2

15. Sugiri. High refined carbohydrate intake play role as important coronary artery disease risk factor.How can it be?. Unpublished.Asmiha.2013

16. Parks EJ, Hellerstein MK. Carbohydrate-induced hypertriacylglycerolemia:hystorical perspective and review of biological mechanisms. Am J Clin Nutr. 2000;71:412-33

17. Kasim-Karakas S, Lane E, Almario R, Mueller W, Walzem R. Effects of dietary fat restriction on particle size of plasma lipoproteins in postmenopausal women. PubMed [internet]. 1997 [cited 2016 Jan 7]; 46(4): 431-6. Available from: Pubmed. 